\title{
Application of Global Dust Detection Index (GDDI) for Sand and Dust Storm Monitoring Over Kingdom of Saudi Arabia
}

\section{Essam Mohammed Alghamdi}

King Abdulaziz University

Mazen Ebraheem Assiri

King Abdulaziz University

Mohsin Jamil Butt ( $\triangle$ mohsinjb@hotmail.com )

King Abdulaziz University https://orcid.org/0000-0003-4012-2806

\section{Research Article}

Keywords: GDDI, DT, DB, AERONET, POCD, POFD

Posted Date: June 4th, 2021

DOI: https://doi.org/10.21203/rs.3.rs-161978/v1

License: (c) (i) This work is licensed under a Creative Commons Attribution 4.0 International License.

Read Full License 


\section{Abstract}

Sand and dust storm events are frequent natural hazards in the Kingdom of Saudi Arabia. Sand and dust storm monitoring is therefore essential to mitigate their environmental-related issues. Satellite remote sensing has been successfully used for sand and dust storm monitoring in various parts of the world. In the current endeavor, we are applying the Global Dust Detection Index (GDDI) on Moderate Resolution Imaging Spectroradiometer (MODIS) data onboard Terra satellite to monitor sand and dust storm activities over the Kingdom of Saudi Arabia. In the current study, fourteen sand and dust storm events are analyzed between the years 2000 to 2017 . The GDDI based results are validated by using MODIS combined Dark Target (DT) and Deep Blue (DB) Aerosol Optical Depth (AOD) product, Meteosat satellite images, ground-based meteorological stations data, and AOD data from AERONET (Aerosol Robotic Network) stations in the study area. Also, GDDI based results are analyzed by determining algorithm accuracy, Probability Of Correct positive Detection (POCD), and Probability Of False positive Detection (POFD). Results of the study show that GDDI can successfully identify sand and dust storm events with various threshold values over the Kingdom of Saudi Arabia. It is envisaged that the outcome of this study would be very beneficial to understand sand and dust storm characteristics in the study region.

\section{Introduction}

Sand and dust storm events are frequent over arid and semi-arid regions of the world and are major contributors to the concentration of aerosols in the atmosphere. Sand and dust storm event has great impacts on environmental dynamics (Tegen et al. 2002; Jickells et al. 2005; Jones \& Christopher 2008) as they can scatter and/or absorb electromagnetic radiation and thereby influence the clouds microphysics and processes of atmospheric chemistry by modifying the ozone level. Sand and dust storm events can indirectly affect the weather systems of the globe and can also trigger global warming which has already received much attention worldwide (IPCC 2007; UNEP 2007; UNEP, WMO 2016; UNEP 2016; UN 2019) due to their potentially catastrophic impacts (Yu et al. 2013; Hu et al. 2014). Thus, sand and dust storm events are one of the imperative environmental apprehensions being faced by both the developed and developing countries of the world. It is therefore crucial that sand and dust storm events should be monitored on regular basis to keep track of the related global environmental issues and adverse health concerns. The Kingdom of Saudi Arabia, which has some of the largest deserts of the world, is essentially vulnerable to the sand and dust storm events thus making their study an area of major concern among environmental scientists. The research on sand and dust storm event, however, has hampered as the spatial coverage of the meteorological stations are quite sparse on the ground in the country. Although, remote sensing, at present, can only provide near-global horizontal coverage with limited vertical resolutions (Banks et al. 2013), increasing concerns about environmental protection has caused the scientist to use satellite data for sand and dust storm monitoring (Tanré et al. 1997; Metcalfe and Buttle 1998; Johansson, Schmetz et al. 2002; Norman, and Gidhagen 2007; Schepanski et al. 2007; Martínez et al. 2009; Schepanski et al. 2012; Sannazzaro et al. 2014). This research aims to address sand and dust storm monitoring over the Kingdom of Saudi Arabia by using satellite and ground-based stations data. 
During the last few decades, remote sensing has proven its major role for sand and dust storm monitoring in different parts of the world (Tanré et al. 1997; Schepanski et al. 2012; Sannazzaro et al. 2014; Butt et al. 2017; Butt \& Mashat 2018). Remote sensing technology has great advantages over traditional measurements due to the extensive global coverage, satisfactory spatial resolution, and repetitive temporal resolutions (Scarratt et al. 2007; Jones \& Christopher 2008). Many research groups have used data from various satellites and sensors for the estimation of aerosols quantity in the atmosphere as well as their relationship with sand and dust storm events (Washington et al. 2003; Kerkmann et al. 2005; Sabbah \& Rybanský 2006; Li et al. 2007; Sabbah \& Hasan 2008; Hutchison et al. 2008; Hoff \& Christopher 2009; Badarinath et al. 2010; Muhammad Akhlaq et al. 2012; Ghasem et al. 2012; Banks \& Brindley 2013). Similarly, researchers have also used geostationary satellite data (for example, Meteosat satellite and Geosynchronous Meteorological Satellite) for sand and dust storm studies in different parts of the world (Liu \& Lin 2004; Banks \& Brindley 2013; Banks et al. 2013; Sannazzaro et al. 2014). However, various errors, especially around regions with low cloud cover (due to similar albedo for dust particles and neighborhoods of clouds) still occur during sand and dust storm monitoring.

Moderate Resolution Imaging Spectroradiometer (MODIS) onboard both Terra and Aqua satellites offer remotely sensed data through its 36 bands in the fields of Land surface, Cloud, Aerosols, Ocean Color Phytoplankton Biogeochemistry, Atmospheric Water Vapor, Atmospheric Temperature, and Ozone. MODIS data can be dedicatedly employed for the study of the environment over a region or the globe. (Kaufman et al. 1997) developed the Dark Target (DT) method, which was later on modified by (Levy et al. 2010) in order to monitor atmospheric aerosol concentration. (Remer et al. 2005) found that the DT technique is unsuccessful over bright reflective surfaces (for example, the Kingdom of Saudi Arabia) and leave a big spatial gap in the estimation of Aerosol Optical Depth (AOD). Thus, the global AOD gap was filled by using Cloud-Aerosol Lidar, the Infrared Pathfinder Satellite Observation (CALIPSO), and the Multi-Angle Imaging Spectroradiometer (MISR) sensors data (Winker et al. 2009) until the development of MODIS Deep Blue (DB) technique proposed by (Hsu et al. 2006). Studies have been conducted which showed that MODIS DB product can successfully produce AOD maps with acceptable uncertainties over bright surfaces (Shi et al. 2011; Li et al. 2012; Shi et al. 2013; Butt et al. 2017). Recently, MODIS combined DT and DB product has also been prepared to produce AOD spatial distribution maps over dark and bright surfaces and is used in the current study.

For sand and dust storm monitoring, MODIS data has also been used successfully by various research groups for the development of algorithm (Li et al. 2007; Martínez et al. 2009). For example, (Qu et al. 2006) presented the Normalized Difference Dust Index (NDDI) using MODIS data to detect sand and dust storm over China. They proposed different threshold values for the detection of various features along with sand and dust storm over the Gobi desert. Researchers have applied NDDI for the detection of sand and dust storm in different parts of the world and found that a slight adjustment in the threshold values is required from that proposed by (Qu et al. 2006). For example, in the detection of sand and dust storm by using NDDI, (Li \& Song 2009) reported slightly lower threshold values over China whilst (Wu et al. 2006) estimated larger threshold values over the ocean than that proposed by (Qu et al. 2006). Similarly, 
(Butt \& Mashat 2018) adjusted a much less threshold value for the detection of sand and dust storm over the Kingdom of Saudi Arabia with the help of NDDI. (Albugami et al. 2019) however concluded that threshold values of NDDI increase from 0.25 to 0.4 from the year 2000 to 2005 . For the detection of sand and dust storm, (Samadi et al. 2014) proposed a new algorithm termed as Global Dust Detection Index (GDDI) using MODIS reflective and thermal Infrared bands data and applied it over Iran. They concluded that sand and dust storm events can be successfully discriminated from other features without any threshold values, both over land and water surfaces. Recently, (Zandkarimi et al. 2020) applied GDDI over Iran with some improvements in the detection of sand and dust storm in the region of study. Interestingly, they also did not propose any threshold values for the discrimination of various features. Many studies have been conducted in the past, which showed that MODIS data is highly suitable for sand and dust storm monitoring (Kaufman et al. 1997; Ignatov et al. 2005; Remer et al. 2005; Butt \& Mashat 2018).

In the current research, GDDI is applied on MODIS data over the Kingdom of Saudi Arabia and threshold values are proposed to discriminate sand and dust storm from other features. GDDI based results are validated by using in situ data from 28 ground stations in the Kingdom of Saudi Arabia as well as data from AERONET (Aerosol Robotic Network) stations in the country. In addition, the model-based results are also verified by using MODIS combined DT-DB products and Meteosat geostationary data over the study region. Finally, the performance of the GDDI is analyzed by calculating algorithm accuracy, Probability Of Correct positive Detection (POCD), and Probability Of False positive Detection (POFD).

\section{Study Area}

The study area, the Kingdom of Saudi Arabia, as shown in Fig. 1, is surrounded by the world's extremely arid regions that are also the main source of sand and dust storm events affecting the country. For example, deserts in Iraq, Jordan, and Syria are in the north, Iranian deserts in the northeast, deserts in UAE in the east, deserts in Yemen and Oman in the southeast, and deserts in African Sahara in the southwest of the country. In addition, the country also has some of the largest deserts in the world (for example, Rab al Khali, An Nafud, and Ad Dhana). Geographically less than $1 \%$ area of the country is feasible for agricultural growth whilst the remaining area is arid or semi-arid. Climatologically, the country's annual average temperature is $25.4^{\circ} \mathrm{C}$ with less than $75 \mathrm{~mm}$ of annual rainfall. The Aziab wind (prefrontal when passes over Sahara desert and deserts in northern Saudi Arabia raise a large amount of dust) and Shamal wind (postfrontal slow-moving/semi-stationary low pressure as well as strong pressure gradients systems that can produce sand and dust storm events lasts from 2-5 days) are the major synoptic conditions over the country. Similarly, the dominant pressure systems (Sudanese Low, Siberian High, Indian Monsoon Low, and Azores High) are among the major contributor to the development of sand and dust storm events over the study area. For example, Siberian High Ridge is the most dominant system in the spring season (more dynamic escalation to strong southerly winds carrying hot air that causes sand and dust storm events) whist the Indian Monsoon Low and Azores High Ridge are the most dominant pressure systems during summer (produces a strong pressure gradient causing Shamal winds leading to the formation of sand and dust storm events). On the other hand, Siberian High, Indian Monsoon Low, and Azores High Ridge are playing an important part during autumn (with a weak pressure gradient 
located over north Africa resulting in a stable condition in the autumn season and thereby very few sand and dust storm events) while the most dominant pressure systems in winter are, Sudanese Low and Siberian High Ridge (these pressure systems are not vibrant enough for the development of sand and dust storm events).

\section{Material}

Near real-time detection of sand and dust storm events over a region can enable us to take precautionary measurements to minimize the related hazards. Thus, sand and dust storm events over the Kingdom of Saudi Arabia are monitored using MODIS data onboard the Terra satellite. Terra's orbit around the Earth is timed so that it passes from north to south across the equator in the morning. Terra is viewing the entire Earth's surface every 1 to 2 days, acquiring data in 36 spectral bands thereby can be very useful depending upon the data availability and application requirements and the research interest. Multispectral bands ( 36 bands) of MODIS ranged from $0.415 \mu \mathrm{m}$ to $14.235 \mu \mathrm{m}$ are an additional advantage in the environmental-related applications. The spatial resolution of MODIS is band dependent ranging from $250 \mathrm{~m}$ to $1 \mathrm{~km}$. MODIS (MOD021 KM) satellite data can be downloaded free of cost from https://modis.gsfc.nasa.gov/data/.

For the selection of MODIS sand and dust storm events, we have used station data in this study. The General Authority of Meteorology and Environmental Protection (GAMEP) is responsible to record and store various meteorological data in the Kingdom of Saudi Arabia as per the World Meteorological Organization (WMO) standards. Sand and dust storm data from 28 ground stations working under GAMEP is retrieved and assessed. Fourteen sand and dust storm events selected from GAMEP data are analyzed in the current study for which the MODIS images are available. Detail of the MODIS images used in the current study is given in Table 1. 
Table 1

Description of GAMEP station data, MODIS satellite data, MODIS DT-DB AOD product, Meteosat satellite data, and AERONET AOD data used in the current study.

\begin{tabular}{|c|c|c|c|c|c|}
\hline S. & $\begin{array}{l}\text { Sand and dust storm events } \\
\text { reported by ground stations }\end{array}$ & $\begin{array}{l}\text { MODIS } \\
\text { satellite } \\
\text { data } \\
(\mathrm{d} / \mathrm{m} / \mathrm{y})\end{array}$ & $\begin{array}{l}\text { MODIS } \\
\text { DT-DB } \\
\text { AOD } \\
\text { product } \\
\text { Monthly / } \\
\text { 5days }\end{array}$ & $\begin{array}{l}\text { Meteosat satellite } \\
\text { data }\end{array}$ & $\begin{array}{l}\text { AERONET } \\
\text { stations } \\
\text { AOD data }\end{array}$ \\
\hline 1 & $\begin{array}{l}\text { Gassim, Hfr-Batin, Qaisumah, } \\
\text { Rafha }\end{array}$ & $18 / 04 / 2000$ & $\begin{array}{l}\text { April } \\
2000 / \\
\\
16-20 \\
\text { April } \\
2000\end{array}$ & $\begin{array}{l}18 / 04 / 2000 \\
(M F G)\end{array}$ & No data \\
\hline 2 & $\begin{array}{l}\text { Ahsa, Arar, Dahran, Dammam, } \\
\text { Guraiat, Hfr-Batin, Jouf, } \\
\text { Qaisumah, Rafha, Sharorah, } \\
\text { Turaif }\end{array}$ & $26 / 03 / 2003$ & $\begin{array}{l}\text { March } \\
2003 / \\
\\
24-28 \\
\text { March } \\
2003\end{array}$ & $\begin{array}{l}26 / 03 / 2003 \\
(\mathrm{MFG})\end{array}$ & No data \\
\hline 3 & $\begin{array}{l}\text { Arar, Guraiat, Hail, Jouf, } \\
\text { Rafha }\end{array}$ & $29 / 04 / 2004$ & $\begin{array}{l}\text { April } \\
2004 \text { / } \\
27 \text { April- } \\
01 \text { May } \\
2004\end{array}$ & $\begin{array}{l}29 / 04 / 2004 \\
(M S G)\end{array}$ & No data \\
\hline 4 & $\begin{array}{l}\text { Baha, Bishah, Rafha, Sharorah, } \\
\text { Wadi-Daw }\end{array}$ & $28 / 04 / 2005$ & $\begin{array}{l}\text { April } \\
2005 / \\
\\
26-30 \\
\text { April } \\
2005\end{array}$ & 28/04/2005(MSG) & No data \\
\hline 5 & $\begin{array}{l}\text { Arar, Gassim, Hail, Jouf } \\
\text { Rafha, Wadi-Daw }\end{array}$ & $23 / 04 / 2006$ & $\begin{array}{l}\text { April } \\
2006 / \\
\\
21-25 \\
\text { April } \\
2006\end{array}$ & 23/04/2006(MSG) & No data \\
\hline 6 & Abha, Jouf, Tabouk, Turaif & $13 / 04 / 2007$ & $\begin{array}{l}\text { April } \\
2007 / \\
\\
11-15 \\
\text { April } \\
2007\end{array}$ & 13/04/2007(MSG) & No data \\
\hline
\end{tabular}




\begin{tabular}{|c|c|c|c|c|c|}
\hline $\begin{array}{l}\text { S. } \\
\text { No }\end{array}$ & $\begin{array}{l}\text { Sand and dust storm events } \\
\text { reported by ground stations }\end{array}$ & $\begin{array}{l}\text { MODIS } \\
\text { satellite } \\
\text { data } \\
(\mathrm{d} / \mathrm{m} / \mathrm{y})\end{array}$ & $\begin{array}{l}\text { MODIS } \\
\text { DT-DB } \\
\text { AOD } \\
\text { product } \\
\text { Monthly / } \\
\text { 5days }\end{array}$ & $\begin{array}{l}\text { Meteosat satellite } \\
\text { data }\end{array}$ & $\begin{array}{l}\text { AERONET } \\
\text { stations } \\
\text { AOD data }\end{array}$ \\
\hline 7 & $\begin{array}{l}\text { Ahsa, Hfr-Batin, Qaisumah, } \\
\text { Yanbu }\end{array}$ & $16 / 04 / 2009$ & $\begin{array}{l}\text { April } \\
2009 \text { / } \\
\\
14-18 \\
\text { April } \\
2009\end{array}$ & 16/04/2009(MSG) & No data \\
\hline 8 & $\begin{array}{l}\text { Dammam, Riyadh, Qaisumah, } \\
\text { Rafha, Yanbu }\end{array}$ & $30 / 04 / 2011$ & $\begin{array}{l}\text { April } \\
2011 \text { / } \\
\\
28 \text { April- } \\
02 \text { May } \\
2011\end{array}$ & 30/04/2011(MSG) & $\begin{array}{l}\text { Solar } \\
\text { Village }\end{array}$ \\
\hline 9 & $\begin{array}{l}\text { Ahsa, Dahran, Dammam } \\
\text { Jeddah, yanbu }\end{array}$ & $18 / 03 / 2012$ & $\begin{array}{l}\text { March } \\
2012 / \\
16-20 \\
\text { March } \\
2012\end{array}$ & 18/03/2012(MSG) & KAUST \\
\hline 10 & Ahsa, Gassim, Madinah, Turaif & $04 / 05 / 2013$ & $\begin{array}{l}\text { May } \\
2013 / \\
\\
02-06 \\
\text { May } \\
2013\end{array}$ & 04/05/2013(MSG) & No data \\
\hline 11 & $\begin{array}{l}\text { Bishah, Gassim, Madinah, } \\
\text { Wadi-Daw }\end{array}$ & $02 / 04 / 2014$ & $\begin{array}{l}\text { April } \\
2014 \text { / } \\
31 \\
\text { March-04 } \\
\text { April } \\
2014\end{array}$ & 02/04/2014(MSG) & No data \\
\hline 12 & $\begin{array}{l}\text { Ahsa, Dammam, New-Riyadh, } \\
\text { Qaisumah, Rafha }\end{array}$ & $01 / 04 / 2015$ & $\begin{array}{l}\text { April } \\
2015 \text { / } \\
30 \\
\text { March-03 } \\
\text { April } \\
2015\end{array}$ & 01/04/2015(MSG) & $\begin{array}{l}\text { Solar } \\
\text { Village }\end{array}$ \\
\hline 13 & Hail, New-Riyadh, Rafha & $11 / 04 / 2016$ & $\begin{array}{l}\text { April } \\
2016 / \\
09-13 \\
\text { April } \\
2016\end{array}$ & 11/04/2016(MSG) & No data \\
\hline
\end{tabular}




\begin{tabular}{|c|c|c|c|c|c|}
\hline $\begin{array}{l}\text { S. } \\
\text { No }\end{array}$ & $\begin{array}{l}\text { Sand and dust storm events } \\
\text { reported by ground stations }\end{array}$ & $\begin{array}{l}\text { MODIS } \\
\text { satellite } \\
\text { data } \\
(\mathrm{d} / \mathrm{m} / \mathrm{y})\end{array}$ & $\begin{array}{l}\text { MODIS } \\
\text { DT-DB } \\
\text { AOD } \\
\text { product } \\
\text { Monthly / } \\
\text { 5days }\end{array}$ & $\begin{array}{l}\text { Meteosat satellite } \\
\text { data }\end{array}$ & $\begin{array}{l}\text { AERONET } \\
\text { stations } \\
\text { AOD data }\end{array}$ \\
\hline 14 & Hail, Jouf, New-Riyadh, Rafha & 19/03/2017 & $\begin{array}{l}\text { March } \\
2017 / \\
17-21 \\
\text { March } \\
2017\end{array}$ & 19/03/2017(MSG) & No data \\
\hline
\end{tabular}

For the validation of the GDDI algorithm, we have used different data sets including, MODIS combined DT-DB AOD product, Meteosat satellite data, ground-based measurements of AOD data from AERONET station, and data from 28 ground-based meteorological stations operated by GAMEP. A combined MODIS DT-DB AOD product for the study period is retrieved from Giovani (https://giovanni.gsfc.nasa.gov). On the other hand, Meteosat data can be downloaded free of cost from the EUMETSAT website (http://eumetsat.int/viewer/index.html). It must be noted that data from Meteosat Second Generation (MSG) is available from February 2004 therefore Meteosat First Generation (MFG) data is also required in order to validate GDDI based results before 2004. Thus, more than 300 MFG and MSG scenes were analyzed using visual interpretation to validate our results. Similarly, there are three AERONET stations in the study region located at different places, that is, AERONET station located in Solar Village near Riyadh (1999-2013), AERONET station located in King Abdullah University of Science and Technology (20122019), and AERONET station located in Hada_El-Sham (2012-2014). Thus, AOD data from AERONET stations for the study period is retrieved from https://aeronet.gsfc.nasa.gov. Finally, the sand and dust storm observational data retrieved from 28 GAMEP ground-based meteorological stations are also considered in order to analyze the performance of the GDDI based results.

\section{Methodology}

Considering the limitations in various developed methodologies (detection threshold change with the season, type of land, and the problem of discrimination from clouds, water, and land soil) (Samadi et al. 2014) developed GDDI using spectral signatures of sand in MODIS band 4 and band 7 for the detection of sand and dust storm events. In the development of GDDI (Samadi et al. 2014) collected training pixels of sand and dust storm over dark surfaces, bright surfaces, and water bodies from MODIS data. By using MODIS images from the Terra satellite they prepared the land cover map of three mainland cover classes (bright land cover, dark land cover, and water bodies) in the study area. They calculated the statistical mean and standard deviation for seven classes (clouds, bright surfaces, dust over bright surfaces, dark surfaces, dust over dark surfaces, water, and dust over water). Finally, they developed a relationship 
between band 4 and band 7 in order to differentiate dust from no-dust pixels over bright surfaces as given in equation 1 .

$$
\mathbf{G D D I}=\frac{B 7-B 4}{B 7+B 4}
$$

where B4 and B7 are reflectances in bands 4 and 7, respectively. The spectral characteristic of sand suggests that strong sand and dust storm signals can be obtained using the difference between band 7 $(2.13-\mu \mathrm{m})$ signals, which are high, and band $4(0.555-\mu \mathrm{m})$ signals, which are relatively much lower.

In the current study, we have applied GDDI as given in equation (1) in order to examine sand and dust storm events over the Kingdom of Saudi Arabia. GAMEP data is used to identify sand and dust storm events for the selection of MODIS images. WMO has designated various codes (30-35 and 98) for sand and dust storm event identification. In the current study, we have used hourly sand and dust storm data from 28 GAMEP ground stations between the years 2000 to 2017. The retrieved sand and dust storm data was standardized to a daily time scale and discrepancies were dealt with methods given in O'Loingsigh et al. (2014) and Rashki et al. (2017). For example, on the sand and dust storm day, only the most intense code was considered among several codes (30-35, and 98) recorded by a station (table 1). For the current study, we have considered sand and dust storm events reported by more than three GAMEP stations on a single day. A total of 144 sand and dust storm events (with the criterion of 3 or more GAMEP stations) have been reported in the study area between the years 2000 to 2017 . However, only 14 MODIS scenes (Table 1) were available after incorporating the above-mentioned criteria. Threshold values for the identification of sand and dust storm events are identified after applying GDDI (equation 1) on 14 MODIS scenes for the Kingdom of Saudi Arabia.

GDDI based sand and dust storm event results are validated using MODIS combined DT-DB AOD product, Meteosat data, AERONET AOD data, and GAMEP data from meteorological stations. In the satellite-based sand and dust storm monitoring the underneath surfaces are divided into cold (mix signature including vegetation, water, etc.) and warm (large desert areas) surfaces. It is well documented that for the production of AOD spatial distribution maps DT and DB methods have been developed for cold and warm surfaces respectively. Considering the climatology and geography of the study region, the Kingdom of Saudi Arabia has been considered as a warm surface (Butt and Mashat 2018). However, it must be noted that sand and dust storm events entering in Kingdom of Saudi Arabia from the northeast and southwest are essentially crossing Arabian Gulf and Red sea respectively. Since the water area is considered as a cold surface while the Kingdom of Saudi Arabia is fundamentally a warm surface therefore we have used MODIS combined DT-DB based AOD product in order to validate GDDI based sand and dust storm events. Thus, monthly average as well as 5 days ( \pm 2 days from the day of sand and dust storm event), MODIS combined DT-DB AOD products for the month (table 1) of sand and dust storm events are retrieved from Giovani. MODIS DT-DB AOD data in NetCDF format is processed using Grads software and monthly as well as 5 days maps are prepared. Similarly, Meteosat satellite data both from 
MFG and MSG (table 1) for 14 sand and dust storm events are analyzed in order to validate GDDI results. It is pertinent to mention here that data from MFG is a visible channel image in black and white from MVIRI (Meteosat Visible and Infrared Imager) instrument directly downloaded from https://www.eumetsat.int/case-studies in jpg format. On the other hand, MSG data from SEVIRI (Spinning Enhanced Visible and Infrared Imager) instrument is used to prepare an RGB color composite of dust products. MSG data downloaded from https://eoportal.eumetsat.int in NetCDF format is processed by using Python script. Once the NetCDF data is processed dust product is prepared by using band 10-band 9 in red, band 9-band 7 in green, and band 9 in blue colors. In the current study, we have also used AERONET station data in order to validate GDDI based sand and dust storm results. Many studies have been conducted in the past using AOD data measured by AERONET station (Sabbah and Hasan, 2008; Butt and Mashat, 2018). Therefore, we retrieved AERONET level 2.0 AOD data for 5 days (the fourth day is the sand and dust storm day) for $500 \mathrm{~nm}$. Sand and dust storm events for which AERONET data were analyzed in order to validate GDDI results are given in Table 1. The GDDI based sand and dust storm events along with GAMEP ground station location are also analyzed using visual interpretation of location map (figure 1). This will enable us to examine the authenticity of ground station data in the study region. In the current study, the performance of the GDDI algorithm is validated by using conventional statistical approaches, that is, accuracy, POCD, and POFD as given in equations 2, 3, and 4 respectively. A similar, approach has been used by Ciren and Kondragunta, (2014) and Zandkarimi et al. (2020) in order to validate Dust Aerosol Index (DOI) and Improved Dust Identification Index (IDII) respectively.

$$
\begin{aligned}
& \text { Accuracy }=\frac{a+d}{a+b+c+d} \times 100 \\
& \text { POCD }=\frac{a}{a+c} \times 100 \\
& \text { POFD }=\frac{b}{a+b} \times 100
\end{aligned}
$$

Where

$\nabla=$ true positives (number of time both GAMEP and GDDI indicate SDS)

$b=$ false positives (number of time when GAMEP indicates no SDS but GDDI indicates SDS)

$c=$ false negatives (number of time when GAMEP indicates SDS and GDDI indicates no SDS)

$d=$ true negatives (number of time both GAMEP and GDDI indicate no SDS)

\section{Results And Discussion}


This study examines the application of GDDI using MODIS data for sand and dust storm monitoring in the Kingdom of Saudi Arabia from the year 2000 to 2017. A total of 14 sand and dust storm cases, shown in Fig. 2, are analyzed during the study period. Based on the spectral analysis of 14 images (Fig. 2) of sand and dust storm events we have proposed threshold values to flag different features in the study area. Since reflectance of water features in MODIS band 4 is higher than that in band 7 therefore negative GDDI values have been used to discriminate clouds/water from other features in the image. In the current study, we have classified the resultant GDDI image into 8 classes (shown in Figs. 5a, 6a, 7a, and $8 \mathrm{a}$ ) based on their threshold values. For example, GDDI values between -1 to -0.8 (dark aqua marine color labeled as 1 ) is used for water features on the ground, GDDI values between - 0.8 to -0.6 (light aqua marine color labeled as 2) is used for clouds features, GDDI values between - 0.6 to -0.4 (aqua marine mixed with light peach color labeled as 3 ) is used for the mild sand and dust particles in the atmosphere mixed with water features, GDDI values between - 0.4 to -0.2 (aqua marine mixed with peach color labeled as 4) is used for the moderate sand and dust particles in the atmosphere mixed with water features, GDDI values between -0.2 to 0.0 (peach color labeled as 5 ) is used for the severe sand and dust particles in the atmosphere mixed with water features, GDDI values between 0.0 to 0.2 (light brown mixed with peach color labeled as 6 ) is used for low concentration of sand and dust particles in the atmosphere over surface features, GDDI values between 0.2 to 0.4 (light brown color labeled as 7 ) is used for high concentration of sand and dust particles in the atmosphere over surface features, and GDDI values greater than 0.4 (dark brown color labeled as 8 ) is used for surface features.

For the validation of GDDI based sand and dust storm events, MFG and MSG images for the day of sand and dust storm events as shown in Fig. 3 are analyzed. Similarly, monthly (for the month of sand and dust storm event) and five days ( \pm 2 days from the day of sand and dust event) average MODIS based combined DT-DB AOD product as shown in Figs. $4 \mathrm{a}$ and $4 \mathrm{~b}$ respectively are also analyzed in order to validate the results. However, during the study period, AERONET station data was available only for three sand and dust storm events. Thus, AOD data for two events from AERONET station at Solar Village and a single event at KAUST are analyzed. It is beyond the scope of this study to discuss in detail all 14 sand and dust storm events. Therefore, we have selected four sand and dust storm events $(2003,2011,2012$, and 2015) for detailed discussion that includes three events reported by AERONET station and one event reported by the highest number (11) of GAMEP stations. GDDI based sand and dust storm event, monthly and five days average MODIS based combined DT-DB AOD products, MFG/MSG images, and five days AERONET level 2.0 AOD data for the years 2003, 2011, 2012, and 2015 are shown in Figs. 5, 6, 7, and 8 respectively and are discussed in the next section.

For the 26 March, 2003 event (reported by 11 GAMEP stations), GDDI result, MFG image, and five days DT-DB AOD product are shown in Figs. 5a, 5b, and $5 \mathrm{c}$ respectively. It is evident from Fig. 5a (GDDI results) that an intense sand and dust storm event (light brown color) is entering from the north and east sides of the study area. Our GDDI results are in accordance with GAMEP data, which indicates that ground stations located in the north (Guraiat, Hfr-Batin, Jouf, Qaisumah, Arar, Rafha, and Turaif), east (Ahsa, 
Dahran, Dammam), and south (Sharorah) regions of the study area have reported sand and dust storm event. Our analysis of Fig. 5a also indicates cloud cover (light aquamarine color) and cloud mixed with mild and moderate sand and dust (aquamarine mixed with light peach color and aquamarine mixed with peach color) over northern and eastern regions of the country. In addition, low to high concentrations of aerosols (light peach and peach color) can be seen (Fig. 5a) over northern, central, western, and southern regions of the study area. Once again, GDDI results are supported by GAMEP data, which shows that 13 stations (Gassim and Hail in the north, Riyadh in the center, Tabuk, Wejh, Madinah, Yenbo, Taif, and Jeddah in the west, Bisha, Gizan, Najran, and Wadi Dawaseer in the south) have reported the widespread of dust in the atmosphere on 26 March 2003. These results are very encouraging and validate proposed GDDI based threshold values (label 3, 4, 5, 6, and 7) for the classification of various sand and dust stormrelated features in the study area. GDDI results are also validated by MFG image (Fig. 5b) for 26 March 2003 , which clearly shows clouds (white color) as well as sand and dust storm (grey color) event in the north and east side of the country. The GDDI results are further validated from the analysis of five-day DTDB AOD product, as shown in Fig. 5c, which indicates a very high concentration of aerosols (orange, red and pink color) in the north and east regions of the study area as compared to the monthly average DTDG AOD product (March 2003 case in Fig. 4a). In addition, a high concentration of aerosols is also visible over a few parts of southern regions in the study area.

For the 30 April 2011 event (reported by 5 GAMEP stations), GDDI result, MSG image, five days DT-DB AOD product, and AERONET station AOD product are shown in Figs. $6 a, 6 b, 6 c$, and $6 \mathrm{~d}$ respectively. An intense sand and dust storm event (light brown color) along with cloud cover (light aquamarine color) can be seen in the eastern, central, and northern parts of the study area from the GDDI result (Fig. 6a). The GDDI results for the 30 April 2011 event are in agreement with GAMEP data, which indicates that ground stations located in the east (Dammam), north (Qaisumah and Rafha), center (Riyadh), and west (Yanbu) of the study area have reported sand and dust storm event. Our analysis of Fig. 6a also highlights cloud cover (light aquamarine color) and clouds mixed with mild and moderate sand and dust (aquamarine mixed with light peach color and aquamarine mixed with peach color) in the northern and central regions of the study area. In addition, a low to a high concentration of aerosols (light peach and peach color) can be seen (Fig. 6a) over the northern, central, western, and southern regions of the study area. The GDDI results are again supported by GAMEP data, which shows that 9 stations (Gassim, Hail, Turaif, Jouf and Hfr Batin in the north, Riyadh in the center, Madinah and Jeddah in the west, and Najran in the south) have reported widespread of dust in the atmosphere on 30 April 2011. Once again GDDI based threshold values assigned to various features in the monitoring of sand and dust storm event are validated in the current study. Similarly, we have also validated GDDI results by MSG image (Fig. 6b) for 30 April 2011, which clearly shows clouds (dark brown color) as well as sand and dust storm event (pink color) in the eastern, central, and northern sides of the country. The analysis of five days of DT-DB AOD product, as shown in Fig. $6 \mathrm{c}$ also indicates a very high concentration of aerosols (orange, red, and pink color) in the eastern, central, and northern regions of the study area as compared to the monthly average DT-DG AOD product (April 2011 case in Fig. 4a). In addition, a high concentration of aerosols is also visible over some western regions of the study area. Finally, 5 days AERONET station data retrieved from 
Solar Village in Riyadh (Fig. 6d) indicates a gradual increase in the concentration of aerosols from day 1 which attain maximum value on day 4 (the day of the event) and started to decrease on day 5.

For the 18 March 2012 event (reported by 5 GAMEP stations), GDDI result, MSG image, five days DT-DB AOD product, and AERONET station AOD product are shown in Figs. $7 \mathrm{a}, 7 \mathrm{~b}, 7 \mathrm{c}$, and $7 \mathrm{~d}$ respectively. It is evident from Fig. 7a (GDDI result) that an intense sand and dust storm event (light brown color) is entering from Arabian Gulf in the eastern part of the study area. Further analysis of Fig. 7a indicates sand and dust storm over the western part of the country as well. The GDDI results are once again in accordance with GAMEP data, which indicates that ground stations located in the eastern region (Ahsa, Dahran, Dammam) and western region (Jeddah and Yanbu) of the study area have reported sand and dust storm event. Our analysis of Fig. 7a also highlights a low to a high concentration of aerosols (light peach and peach color) over the northern, central, western, and southern regions of the study area. Once again, GDDI results are supported by GAMEP data, which shows that 20 stations (Arar, Gassim, Hail, Turaif, Tabuk, Qaisumah, Rafha, and Hfr Batin in the north, Riyadh in the center, Makkah, Madinah and Taif in the west, and Abha, Baha, Bisha, Gizan, Sharorah, Khamis Mushat, Wadi Dawaser and Najran in the south) have reported widespread of dust in the atmosphere on 18 March 2012. These results essentially validated the proposed GDDI based threshold values over the study area. The GDDI results are also validated by MSG image (Fig. 7b) for 18 March 2012, which clearly shows intense sand and dust storm (pink color) event entering from eastern part over Arabian Gulf in the study area. The analysis of five days DT-DB AOD product, as shown in Fig. 7c indicates a very high concentration of aerosols (orange, red, and pink color) over large parts of the country including eastern, central, southern, and western parts as compared to the monthly average DT-DB AOD product (March 2012 case in Fig. 4a). In addition, moderate aerosols quantity is also visible over some northern parts of the study area. The widespread of aerosols covering the entire study area is also supported by the GAMEP data as 20 ground stations have reported moderate to a high concentration of aerosols. Similarly, 5 days AERONET station data retrieved from KAUST (Fig. 7d) indicates a gradual increase (from day 1) which turned into a large amount of aerosol concentration on day 4 (the day of the event) and ultimately start decreasing on day 5 .

For the 01 April 2015 event (reported by 5 GAMEP stations), GDDI result, MSG image, five days DT-DB AOD product, and AERONET station AOD product are shown in Figs. $8 \mathrm{a}, 8 \mathrm{~b}, 8 \mathrm{c}$, and $8 \mathrm{~d}$ respectively. Unfortunately, a complete MODIS scene of the study area for the said date was unavailable however, moderate sand and dust storm traces (light brown mixed with peach color) can be seen over the eastern, central, and northeast parts (top right hand corner of Fig. 8a) of the study area. Our GDDI results are again in agreement with GAMEP data, which indicates that ground stations are located in the east (Dammam and Ahsa), north (Qaisumah and Rafha), and center (Riyadh) of the study area have reported sand and dust storm event. Our analysis of Fig. 8a also highlights a low to a high concentration of aerosols (light peach and peach color) over the western, northern, and southern regions of the study area. Once again GDDI results are supported by GAMEP stations, which shows that 10 stations (Gassim, Hail, Arar, Tabuk, and Jouf in the north, Makkah, Wejh, and Yanbu in the west, and Wadi Dawaseer and Gizan in the south) have reported widespread of dust in the atmosphere. These are encouraging results that validated proposed GDDI based threshold values (label 3, 4, 5, 6, and 7) for the classification of various 
sand and dust storm-related features in the study area. The GDDI results are also validated by MSG image (Fig. 8b) for 01 April 2015, which clearly shows sand and dust storm (pink and dark pink color) events in the northern, eastern, and central regions of the country. The analysis of five days DT-DB AOD product, as shown in Fig. 8c, indicates a high concentration (orange, red, and pink color) of aerosols in the eastern, central, and partly northern regions of the study area as compared to the monthly average DTDB AOD product (April 2015 case in Fig. 4a). Finally, 5 days AERONET station data retrieved from Solar Village in Riyadh (Fig. 8d) indicates a gradual increase in the concentration of aerosols from day 1 which attain maximum value on day 4 (the day of the event) and started to decrease on day 5.

The robustness of the GDDI algorithm results are evaluated by estimating accuracy (Eq. 2), POCD (Eq. 3), and POFD (Eq. 4) methods. For the 14 sand and dust storm events considered in the current study over the KSA the estimated accuracy of the GDDI based result is $76 \%$, POCD is $93 \%$, and POFD is $28 \%$. These results indicate that GDDI can be applied successfully for the monitoring of sand and dust storm events over the KSA. In addition, GDDI can be used to classify various sand and dust features by assigning different threshold values.

\section{Conclusion}

Every year, early warnings about natural calamity help get millions of people out of harm way before the danger comes. It is now clear that scientific studies can protect us from these hazards by using data from different satellites and air quality information. More than 15 organizations, supported by WMO, currently provide daily sand and dust storm forecasts in different geographic regions of the world thus, integrating research and user communities (for example, medical, aeronautical, agricultural users, etc.). Their mission is to achieve comprehensive, coordinated, and sustained observations and modeling capabilities of sand and dust storm monitoring in order to increase the understanding and improve the monitoring and prediction capabilities.

The focus of current research is to evaluate the suitability of GDDI for sand and dust storm monitoring over the Kingdom of Saudi Arabia. Samadi et al. (2014) and Zandkarimi et al. (2020) concluded in different studies over Iran that no threshold values are required for the identification of sand and dust storm event by using the GDDI method. However, in current research, we have successfully identified threshold values for the identification of different features (for example, cloud cover, sand and dust mixed with clouds, low sand and dust in the atmosphere, moderate sand and dust storm, and heavy sand and dust storm) during the study period over Kingdom of Saudi Arabia. The GDDI threshold values assigned for the identification of different features is successfully validated by using GAMEP data. This study concluded that generally, GDDI can successfully identify sand and dust storm with a thunderstorm over the surface as well as water features in the study area. This study also concluded that thin clouds and outspread of thin dust can also be identified with the help of threshold values used in the application of GDDI. 
It is pertinent that one day these outcomes could help millions of people in different parts of the world. Research forecasting products from atmospheric dust models may substantially contribute to risk reduction in many areas of societal benefit but will rely on real-time delivery of products to people in the Kingdom of Saudi Arabia with high precision.

\section{Declarations}

\section{Acknowledgment}

Analyses and visualizations used in this study were produced with the Giovanni online data system, developed and maintained by the NASA GES DISC. We would also like to express our gratitude to the Goddard Earth Sciences Data and Information Services Center (GES DISC) for providing MODIS data and AERONET AOD data. In addition to this, the authors are highly indebted to GAMEP for providing station data for all 28 meteorological stations situated in the study area. Finally, the authors would also like to thank EUMETSAT for providing MFG and MSG satellite data used in the current research.

\section{Declaration}

No funding was received for conducting this study. The authors declare no competing financial interests.

\section{References}

Albugami S, Palmer S, Cinnamon J, Meersmans J. 2019. Spatial and temporal variations in the incidence of dust storms in Saudi Arabia revealed from in situ observations. Geosci. 9(4).

Badarinath KVS, Kharol SK, Kaskaoutis DG, Sharma AR, Ramaswamy V, Kambezidis HD. 2010. Longrange transport of dust aerosols over the Arabian Sea and Indian region - A case study using satellite data and ground-based measurements. Glob Planet Change. 72(3):164-181.

Banks JR, Brindley HE. 2013. Evaluation of MSG-SEVIRI mineral dust retrieval products over North Africa and the Middle East. Remote Sens Environ. 128.

Banks JR, Brindley HE, Flamant C, Garay MJ, Hsu NC, Kalashnikova O V., Klüser L, Sayer AM. 2013. Intercomparison of satellite dust retrieval products over the west African Sahara during the Fennec campaign in June 2011. Remote Sens Environ. 136:99-116.

Butt MJ, Assiri ME, Ali MA. 2017. Assessment of AOD variability over Saudi Arabia using MODIS Deep Blue products. Environ Pollut. 231.

Butt MJ, Mashat AS. 2018. MODIS satellite data evaluation for sand and dust storm monitoring in Saudi Arabia. Int J Remote Sens. 
Ghasem A, Shamsipour AA, Miri M, Safarrad T. 2012. Synoptic and remote sensing analysis of dust events in southwestern Iran. Nat Hazards. 64(2):1625-1638.

Hoff RM, Christopher SA. 2009. Remote sensing of particulate pollution from space: Have we reached the promised land? J Air Waste Manag Assoc. 59(6):645-675.

Hsu NC, Tsay SC, King MD, Herman JR. 2006. Deep Blue retrievals of Asian aerosol properties during ACEAsia. IEEE Trans Geosci Remote Sens. 44(11):3180-3195.

Hu D, Zhang L, Wang H. 2014. Aerosol Optical Depth investigated with satellite remote sensing observations in China. In: IOP Conf Ser Earth Environ Sci. [place unknown].

Hutchison KD, lisager BD, Kopp TJ, Jackson JM. 2008. Distinguishing Aerosols from Clouds in Global, Multispectral Satellite Data with Automated Cloud Classification Algorithms. J Atmos Ocean Technol. 25(4).

Ignatov A, Minnis P, Loeb N, Wielicki B, Miller W, Sun-Mack S, Tanré D, Remer L, Laszlo I, Geier E. 2005. Two MODIS aerosol products over ocean on the Terra and Aqua CERES SSF datasets. J Atmos Sci. 62(4):1008-1031.

IPCC. 2007. Climate Change 2007 Synthesis Report. [place unknown].

Jickells TD, An ZS, Andersen KK, Baker AR, Bergametti C, Brooks N, Cao JJ, Boyd PW, Duce RA, Hunter KA, et al. 2005. Global iron connections between desert dust, ocean biogeochemistry, and climate. Science (80-).

Johansson C, Norman M, Gidhagen L. 2007. Spatial \& temporal variations of PM10 and particle number concentrations in urban air. Environ Monit Assess. 127(1-3):477-487.

Jones TA, Christopher SA. 2008. Seasonal variation in satellite-derived effects of aerosols on clouds in the Arabian Sea. J Geophys Res Atmos.

Kaufman YJ, Tanré D, Remer LA, Vermote EF, Chu A, Holben BN. 1997. Operational remote sensing of tropospheric aerosol over land from EOS moderate resolution imaging spectroradiometer. J Geophys Res Atmos. 102(14):17051-17067.

Kerkmann J, Roesli H., Bridge G, König M. 2005. APPLICATIONS OF METEOSAT SECOND GENERATION (MSG) RGB COMPOSITES WITH CHANNELS AND THEIR INTERPRETATION.

Levy RC, Remer LA, Kleidman RG, Mattoo S, Ichoku C, Kahn R, Eck TF. 2010. Global evaluation of the Collection 5 MODIS dark-target aerosol products over land. Atmos Chem Phys. 10(21):10399-10420.

Li J, Zhang P, Schmit TJ, Schmetz J, Menzel WP. 2007. Quantitative monitoring of a Saharan dust event with SEVIRI on Meteosat-8. Int J Remote Sens. 28(10):2181-2186. 
Li Q, Li C, Mao J. 2012. Evaluation of atmospheric aerosol optical depth products at ultraviolet bands derived from MODIS products. Aerosol Sci Technol. 46(9):1025-1034.

Li X, Song W. 2009. Dust storm detection based on modis data. (47):169-172.

Liu GR, Lin TH. 2004. Application of geostationary satellite observations for monitoring dust storms of Asia. Terr Atmos Ocean Sci. 15(5):825-837.

Martínez MA, Ruiz J, Cuevas E. 2009. Use of SEVIRI images and derived products in a WMO Sand and dust Storm Warning System. IOP Conf Ser Earth Environ Sci. 7(1):012004.

Metcalfe RA, Buttle JM. 1998. A statistical model of spatially distributed snowmelt rates in a boreal forest basin. Hydrol Process. 12(10-11):1701-1722.

Muhammad Akhlaq, Sheltami TR, Mouftah HT. 2012. A review of techniques and technologies for sand and dust storm detection. Rev Environ Sci Biotechnol. 11(3):305-322.

Notaro M, Alkolibi F, Fadda E, Bakhrjy F. 2013. Trajectory analysis of Saudi Arabian dust storms. J Geophys Res Atmos. 118(12):6028-6043.

Qu JJ, Hao X, Kafatos M, Wang L. 2006. Asian dust storm monitoring combining terra and aqua MODIS SRB measurements. IEEE Geosci Remote Sens Lett. 3(4):484-486.

Remer LA, Kaufman YJ, Tanré D, Mattoo S, Chu DA, Martins J V., Li RR, Ichoku C, Levy RC, Kleidman RG, et al. 2005. The MODIS aerosol algorithm, products, and validation. J Atmos Sci. 62(4):947-973.

Sabbah I, Hasan FM. 2008. Remote sensing of aerosols over the Solar Village, Saudi Arabia. Atmos Res. 90(2-4):170-179.

Sabbah I, Rybanský M. 2006. Galactic cosmic ray modulation during the last five solar cycles. J Geophys Res. 111(A1):A01105.

Samadi M, Boloorani AD, Alavipanah SK, Mohamadi H, Najafi MS. 2014. Global dust Detection Index (GDDI); A new remotely sensed methodology for dust storms detection. J Environ Heal Sci Eng. 12(1):114.

Sannazzaro F, Filizzola C, Marchese F, Corrado R, Paciello R, Mazzeo G, Pergola N, Tramutoli V. 2014. Identification of dust outbreaks on infrared MSG-SEVIRI data by using a Robust Satellite Technique (RST). Acta Astronaut. 93:64-70.

Scarratt MG, Levasseur M, Michaud S, Roy S. 2007. DMSP and DMS in the Northwest Atlantic: Latesummer distributions, production rates and sea-air fluxes. In: Aquat Sci. Vol. 69. [place unknown]: Springer; p. 292-304. 
Schepanski K, Tegen I, Laurent B, Heinold B, Macke A. 2007. A new Saharan dust source activation frequency map derived from MSG-SEVIRI IR-channels. Geophys Res Lett. 34(18).

Schepanski K, Tegen I, Macke A. 2012. Comparison of satellite based observations of Saharan dust source areas. Remote Sens Environ. 123:90-97.

Schmetz J, Pili P, Tjemkes S, Just D, Kerkmann J, Rota S, Ratier A. 2002. An introduction to Meteosat Second Generation (MSG). Bull Am Meteorol Soc. 83(7):977-992.

Shi Y, Zhang J, Reid JS, Hyer EJ, Eck TF, Holben BN, Kahn RA. 2011. A critical examination of spatial biases between MODIS and MISR aerosol products - application for potential AERONET deployment. Atmos Meas Tech. 4(12):2823-2836.

Shi Y, Zhang J, Reid JS, Hyer EJ, Hsu NC. 2013. Critical evaluation of the MODIS Deep Blue aerosol optical depth product for data assimilation over North Africa. Atmos Meas Tech. 6(4):949-969.

Tanré D, Kaufman YJ, Herman M, Mattoo S. 1997. Remote sensing of aerosol properties over oceans using the MODIS/EOS spectral radiances. J Geophys Res Atmos. 102(14):16971-16988.

Tegen I, Harrison SP, Kohfeld K, Prentice IC, Coe M, Heimann M. 2002. Impact of vegetation and preferential source areas on global dust aerosol: Results from a model study. J Geophys Res Atmos.

J19. 2019. United Nations Coalition on Combatting Sand and Dust Storms (SDS) Terms of Reference. [place unknown].

UNEP, WMO U. 2016. Global Assessment of Sand and Dust Storms [Internet]. [place unknown]; [accessed 2021 Jan 4]. http://www.un.org/Depts/Cartographic/english/htmain.htm

UNEP. 2007. Global Environment Outlook 4 | UNEP - UN Environment Programme [Internet]. [accessed 2021 Jan 4]. https://www.unenvironment.org/resources/global-environment-outlook-4

UNEP. 2016. Global Assessment of Sand and Dust Storms [Internet]. [place unknown]; [accessed 2021 Jan 4]. http://www.un.org/Depts/Cartographic/english/htmain.htm

Washington R, Todd M, Middleton NJ, Goudie AS. 2003. Dust-storm source areas determined by the total ozone monitoring spectrometer and surface observations. Ann Assoc Am Geogr. 93(2):297-313.

Winker DM, Vaughan MA, Omar A, Hu Y, Powell KA, Liu Z, Hunt WH, Young SA. 2009. Overview of the CALIPSO mission and CALIOP data processing algorithms. J Atmos Ocean Technol. 26(11):2310-2323.

Wu L, Braun SA, Qu JJ, Hao X. 2006. Simulating the formation of Hurricane Isabel (2003) with AIRS data. Geophys Res Lett. 33(4):L04804.

Yu Y, Notaro M, Liu Z, Kalashnikova O, Alkolibi F, Fadda E, Bakhrjy F. 2013. Assessing temporal and spatial variations in atmospheric dust over Saudi Arabia through satellite, radiometric, and station data. $J$ 
Geophys Res Atmos.

Zandkarimi A, Fatehi P, Shah-Hoseini R. 2020. An improved dust identification index (IDII) based on MODIS observation. Int J Remote Sens. 41(20):8048-8068.

\section{Tables}

Table 1. Description of GAMEP station data, MODIS satellite data, MODIS DT-DB AOD product, Meteosat satellite data, and AERONET AOD data used in the current study. 


\begin{tabular}{|c|c|c|c|c|c|}
\hline $\begin{array}{l}\text { S. } \\
\text { No }\end{array}$ & $\begin{array}{l}\text { Sand and dust storm events } \\
\text { reported by ground stations }\end{array}$ & $\begin{array}{l}\text { MODIS } \\
\text { satellite } \\
\text { data } \\
(\mathrm{d} / \mathrm{m} / \mathrm{y})\end{array}$ & $\begin{array}{c}\text { MODIS } \\
\text { DT-DB } \\
\text { AOD } \\
\text { product } \\
\text { Monthly / } \\
\text { 5days }\end{array}$ & $\begin{array}{c}\text { Meteosat satellite } \\
\text { data }\end{array}$ & $\begin{array}{l}\text { AERONET } \\
\text { stations } \\
\text { AOD data }\end{array}$ \\
\hline 1 & $\begin{array}{l}\text { Gassim, Hfr-Batin, Qaisumah, } \\
\text { Rafha }\end{array}$ & $18 / 04 / 2000$ & $\begin{array}{l}\text { April } \\
2000 / \\
16-20 \\
\text { April } \\
2000\end{array}$ & $\begin{array}{l}18 / 04 / 2000 \\
\text { (MFG) }\end{array}$ & No data \\
\hline 2 & $\begin{array}{l}\text { Ahsa, Arar, Dahran, } \\
\text { Dammam, Guraiat, Hfr-Batin, } \\
\text { Jouf, Qaisumah, Rafha, } \\
\text { Sharorah, Turaif }\end{array}$ & $26 / 03 / 2003$ & $\begin{array}{l}\text { March } \\
2003 / \\
24-28 \\
\text { March } \\
2003\end{array}$ & $\begin{array}{c}26 / 03 / 2003 \\
\text { (MFG) }\end{array}$ & No data \\
\hline 3 & $\begin{array}{l}\text { Arar, Guraiat, Hail, Jouf, } \\
\text { Rafha }\end{array}$ & $29 / 04 / 2004$ & $\begin{array}{l}\text { April } \\
2004 \text { / } \\
27 \text { April- } \\
01 \text { May } \\
2004\end{array}$ & $\begin{array}{c}29 / 04 / 2004 \\
\text { (MSG) }\end{array}$ & No data \\
\hline 4 & $\begin{array}{l}\text { Baha, Bishah, Rafha, } \\
\text { Sharorah, Wadi-Daw }\end{array}$ & $28 / 04 / 2005$ & $\begin{array}{l}\text { April } \\
2005 / \\
26-30 \\
\text { April } \\
2005\end{array}$ & 28/04/2005(MSG) & No data \\
\hline 5 & $\begin{array}{l}\text { Arar, Gassim, Hail, Jouf } \\
\text { Rafha, Wadi-Daw }\end{array}$ & $23 / 04 / 2006$ & $\begin{array}{l}\text { April } \\
2006 / \\
21-25 \\
\text { April } \\
2006\end{array}$ & 23/04/2006(MSG) & No data \\
\hline 6 & Abha, Jouf, Tabouk, Turaif & $13 / 04 / 2007$ & $\begin{array}{l}\text { April } \\
2007 / \\
11-15 \\
\text { April } \\
2007\end{array}$ & $13 / 04 / 2007$ (MSG) & No data \\
\hline 7 & $\begin{array}{l}\text { Ahsa, Hfr-Batin, Qaisumah, } \\
\text { Yanbu }\end{array}$ & $16 / 04 / 2009$ & $\begin{array}{l}\text { April } \\
2009 / \\
14-18 \\
\text { April } \\
2009\end{array}$ & 16/04/2009(MSG) & No data \\
\hline 8 & $\begin{array}{l}\text { Dammam, Riyadh, Qaisumah, } \\
\text { Rafha, Yanbu }\end{array}$ & $30 / 04 / 2011$ & $\begin{array}{c}\text { April } \\
2011 / \\
28 \text { April- } \\
02 \text { May } \\
2011\end{array}$ & 30/04/2011(MSG) & $\begin{array}{c}\text { Solar } \\
\text { Village }\end{array}$ \\
\hline 9 & $\begin{array}{l}\text { Ahsa, Dahran, Dammam } \\
\text { Jeddah, yanbu }\end{array}$ & $18 / 03 / 2012$ & $\begin{array}{l}\text { March } \\
2012 / \\
16-20 \\
\text { March } \\
2012\end{array}$ & 18/03/2012(MSG) & KAUST \\
\hline 10 & $\begin{array}{l}\text { Ahsa, Gassim, Madinah, } \\
\text { Turaif }\end{array}$ & $04 / 05 / 2013$ & May 2013 & 04/05/2013(MSG) & No data \\
\hline
\end{tabular}




\begin{tabular}{|c|c|c|c|c|c|}
\hline & & & $\begin{array}{c}02-06 \\
\text { May } 2013\end{array}$ & & \\
\hline 11 & $\begin{array}{l}\text { Bishah, Gassim, Madinah, } \\
\text { Wadi-Daw }\end{array}$ & $02 / 04 / 2014$ & $\begin{array}{c}\text { April } \\
2014 / \\
31 \\
\text { March-04 } \\
\text { April } \\
2014\end{array}$ & 02/04/2014(MSG) & No data \\
\hline 12 & $\begin{array}{l}\text { Ahsa, Dammam, New-Riyadh, } \\
\text { Qaisumah, Rafha }\end{array}$ & $01 / 04 / 2015$ & $\begin{array}{c}\text { April } \\
2015 / \\
30 \\
\text { March-03 } \\
\text { April } \\
2015\end{array}$ & 01/04/2015(MSG) & $\begin{array}{c}\text { Solar } \\
\text { Village }\end{array}$ \\
\hline 13 & Hail, New-Riyadh, Rafha & $11 / 04 / 2016$ & $\begin{array}{c}\text { April } \\
2016 / 1 \\
09-13 \\
\text { April } \\
2016\end{array}$ & 11/04/2016(MSG) & No data \\
\hline 14 & $\begin{array}{l}\text { Hail, Jouf, New-Riyadh, } \\
\text { Rafha }\end{array}$ & $19 / 03 / 2017$ & $\begin{array}{l}\text { March } \\
2017 \text { / } \\
17-21 \\
\text { March } \\
2017\end{array}$ & 19/03/2017(MSG) & No data \\
\hline
\end{tabular}

\section{Figures}

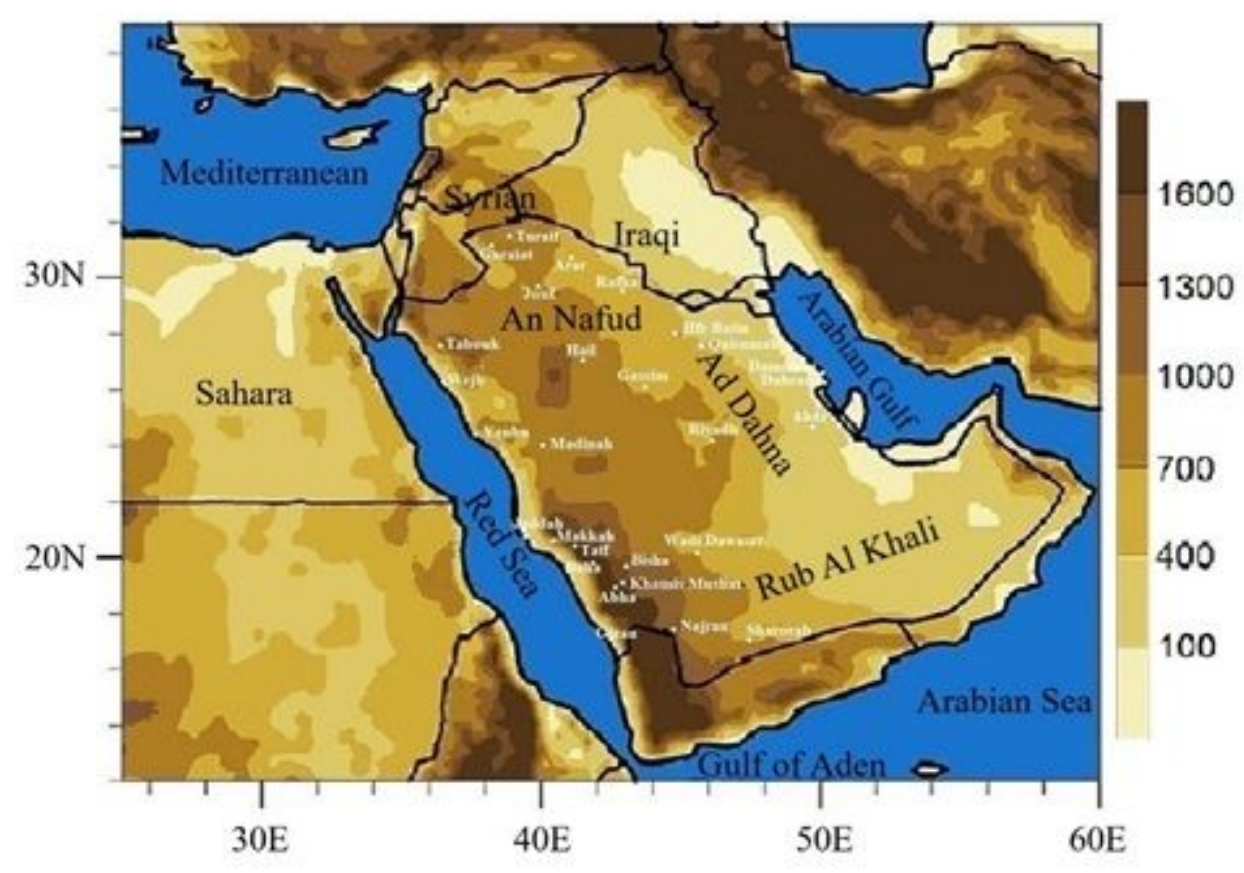


Study area with main deserts (Sahara, Rub Al Khali, An Nafud, Ad Dahna, Syrian, and Iraqi) that are contributing sand and dust events in the region. The location of GAMEP ground stations are shown in white color text (modified after (Notaro et al. 2013)).

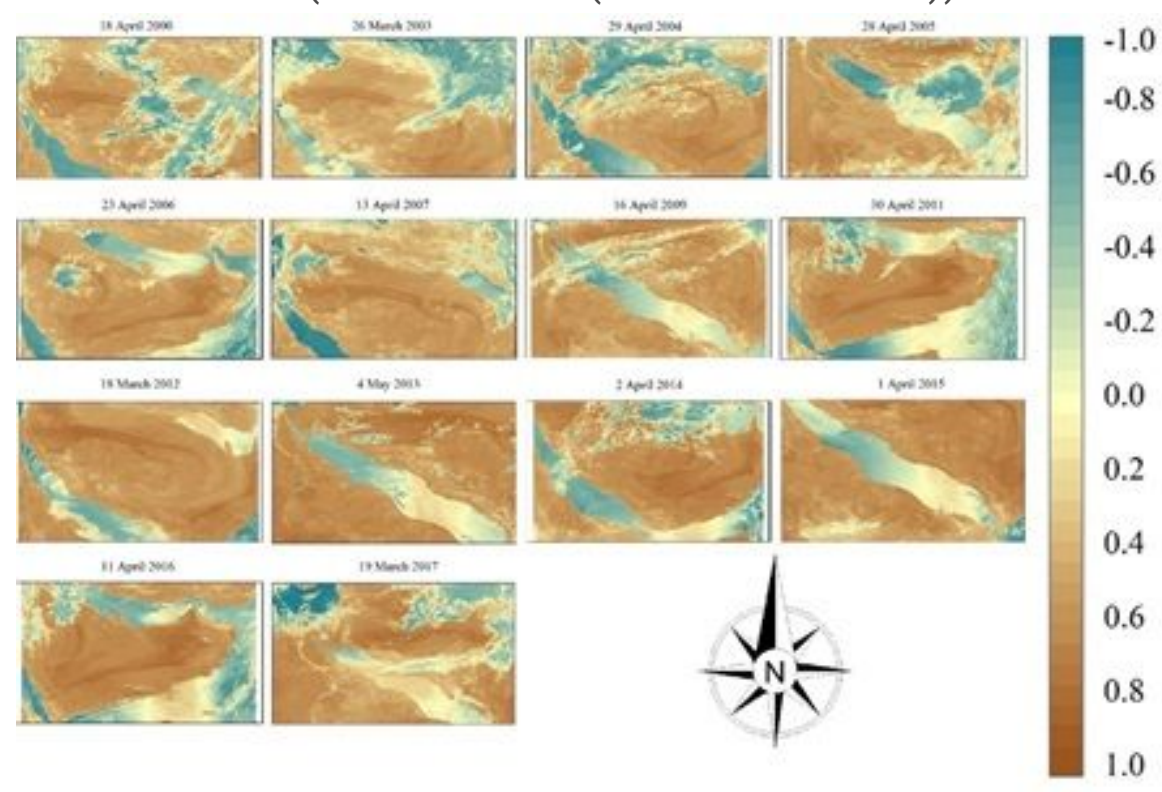

\section{Figure 2}

GDDI based resultant images of 14 sand and dust storm events between the year 2000 to 2017 over the Kingdom of Saudi Arabia. 

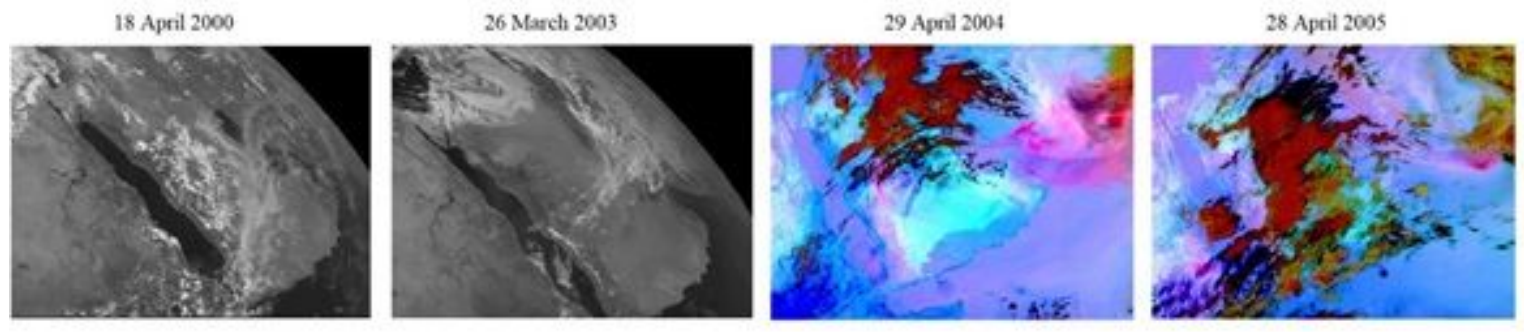

23 April 2006

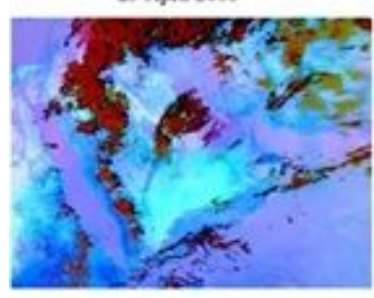

18 March 2012

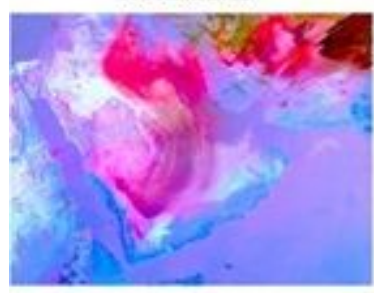

11 April 2016

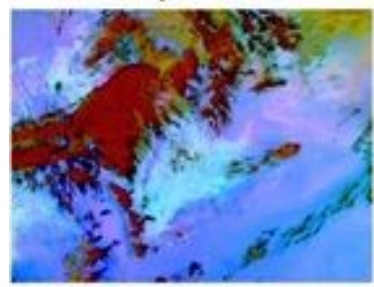

13 April 2007

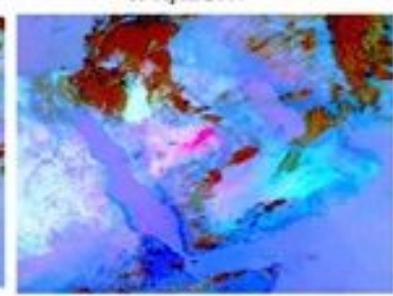

4 May 2013

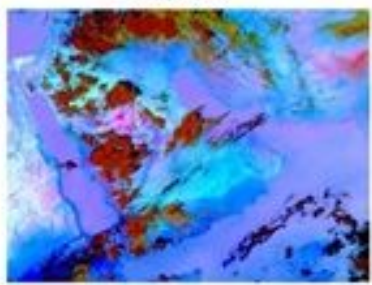

19 March 2013

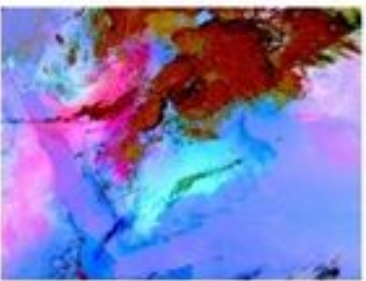

16 Apoil 2009

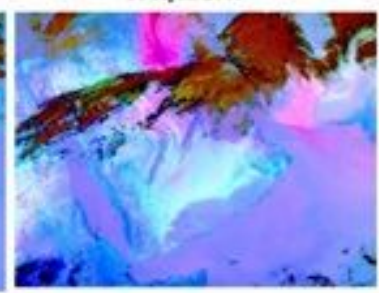

2 April 2014

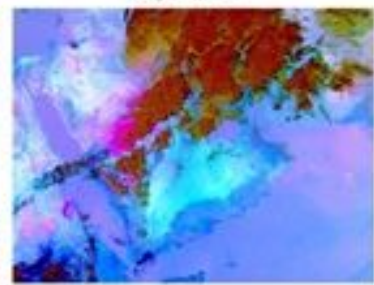

30 April 2011

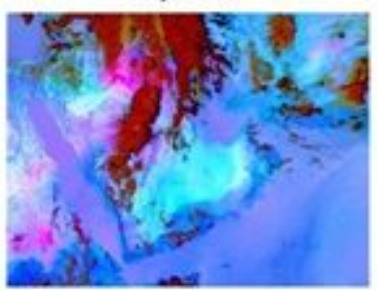

1 April 2015

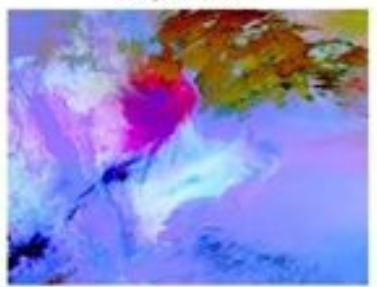

\section{Figure 3}

MFG and MSG images of 14 sand and dust storm events between the years 2000 to 2017 over the Kingdom of Saudi Arabia. MFG images are in greyscale whilst MSG based dust product (band10-band9 in red, band9-band7 in green, and band9 in blue) are color images. 

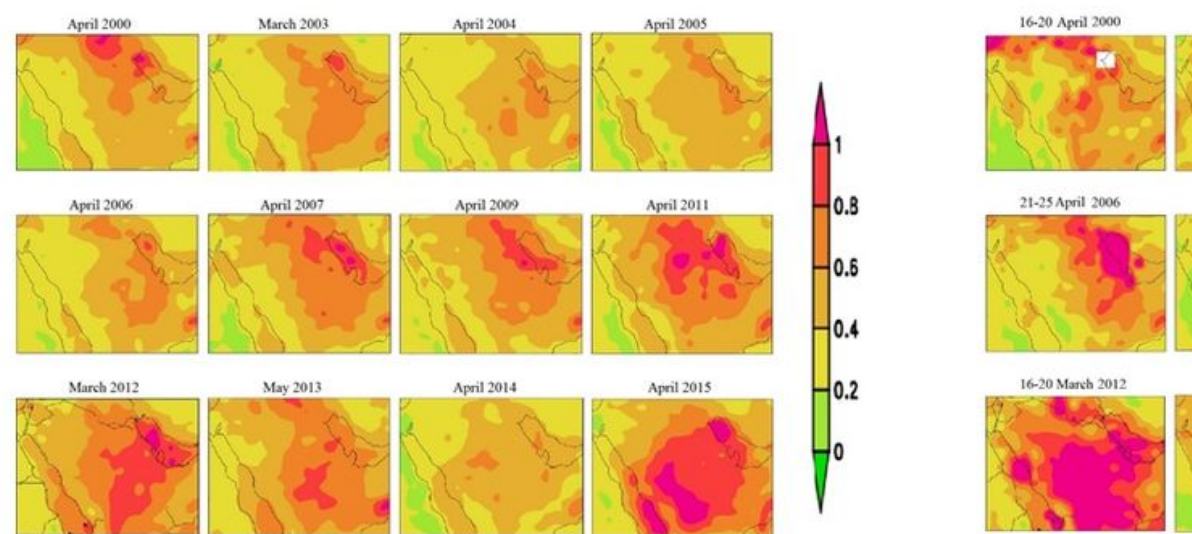

24.28 March 2003

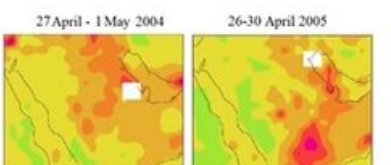

$21-25$ April 2006

11-15April 2007

14-18April 2009

28 April - 2 May 2011
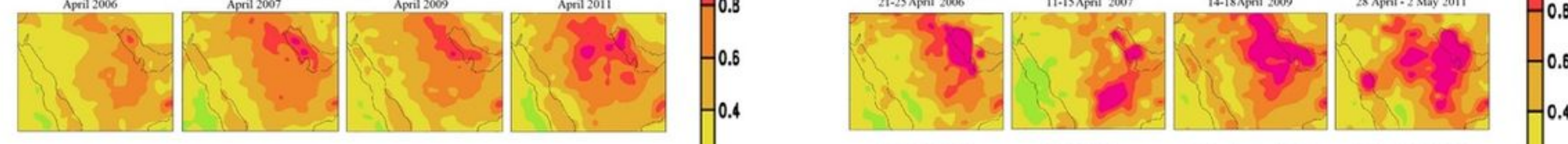

May 2013

April 2014

April 2015
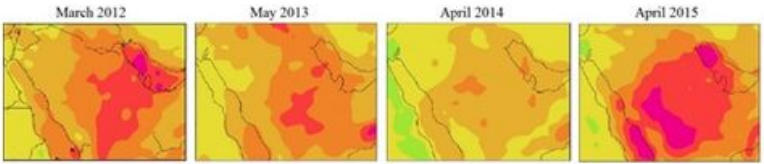

16-20 Marcb 2012

31 March -4 Apnil 2014

30 March-3April 2015
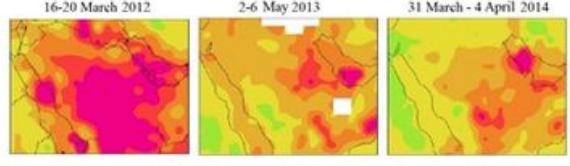

17.21 March 2017
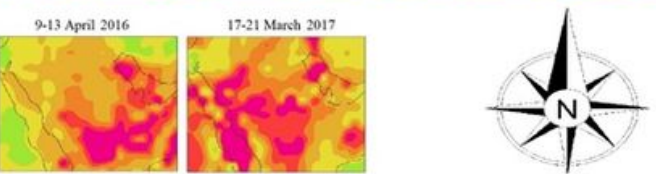

Figure 4

4a. MODIS DT-DB AOD average product for the months of 14 sand and dust storm events between the year 2000 to 2017 over the Kingdom of Saudi Arabia. 4b. MODIS DT-DB AOD 5 days ( \pm 2 days from the day of sand and dust event) average product for 14 sand and dust storm events between the year 2000 to 2017 over the Kingdom of Saudi Arabia. 


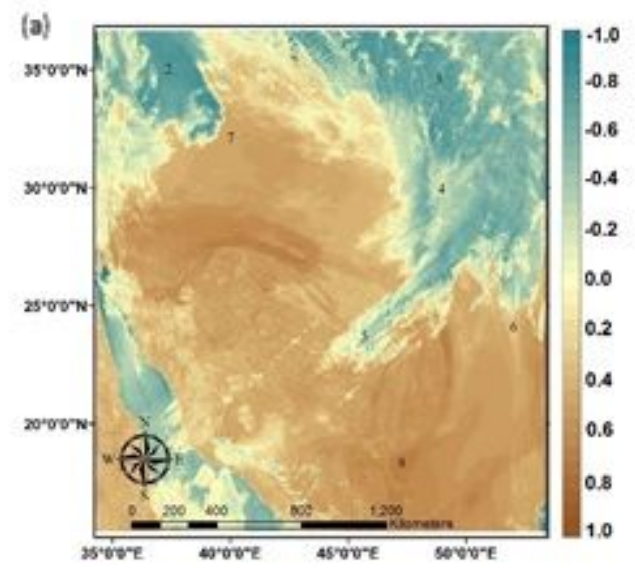

(b)
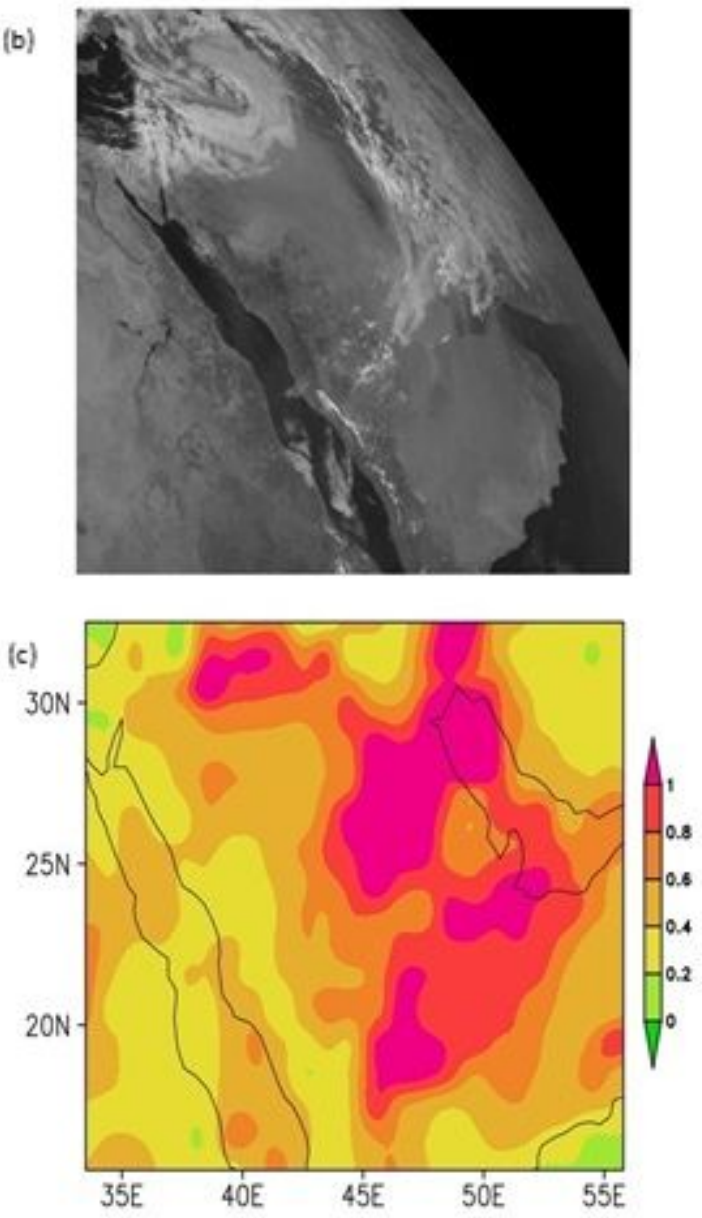

Figure 5

Sand and dust storm event of 26 March 2003 over study area (a) MODIS GDDI image, (b) MFG image, and (c) MODIS DT-DB AOD 5 day product. 
(a)

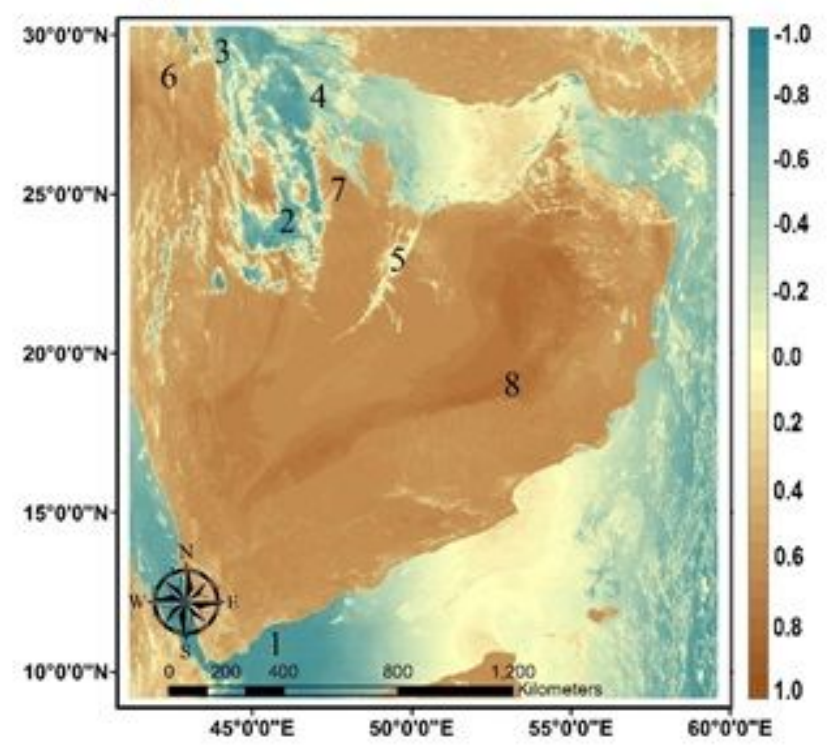

(c)

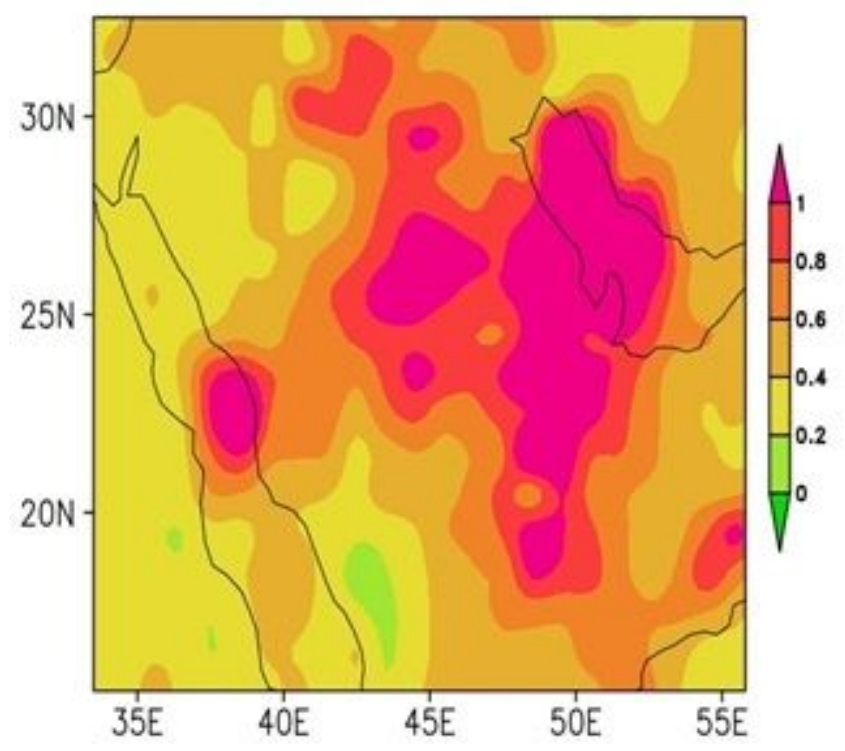

(b)

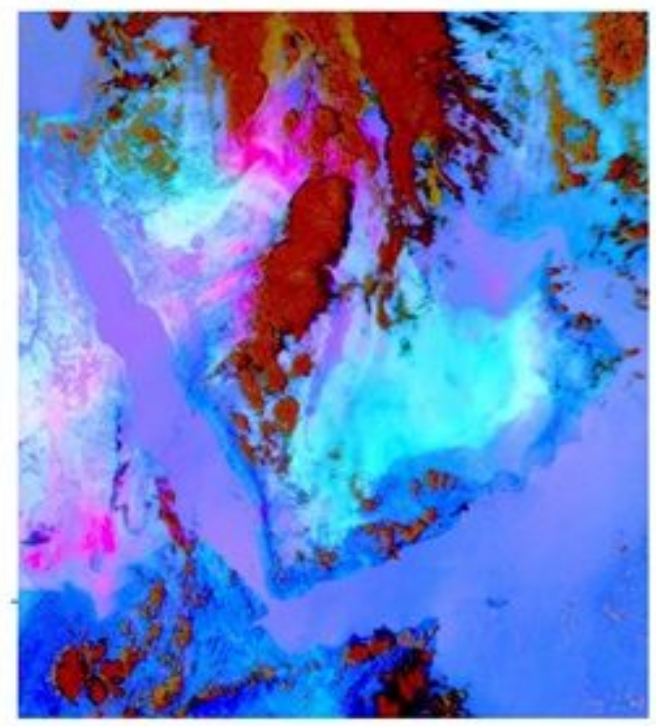

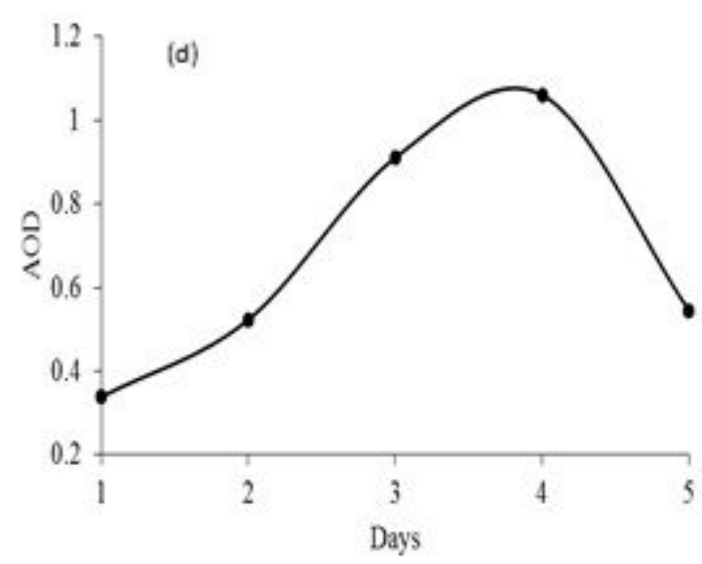

Figure 6

Sand and dust storm event of 30 April 2011 over the study area (a) MODIS GDDI image, (b) MSG image, (c) MODIS DT-DB AOD 5 day product, and (d) AERONET station data of AOD from Solar Village for 5 days. 


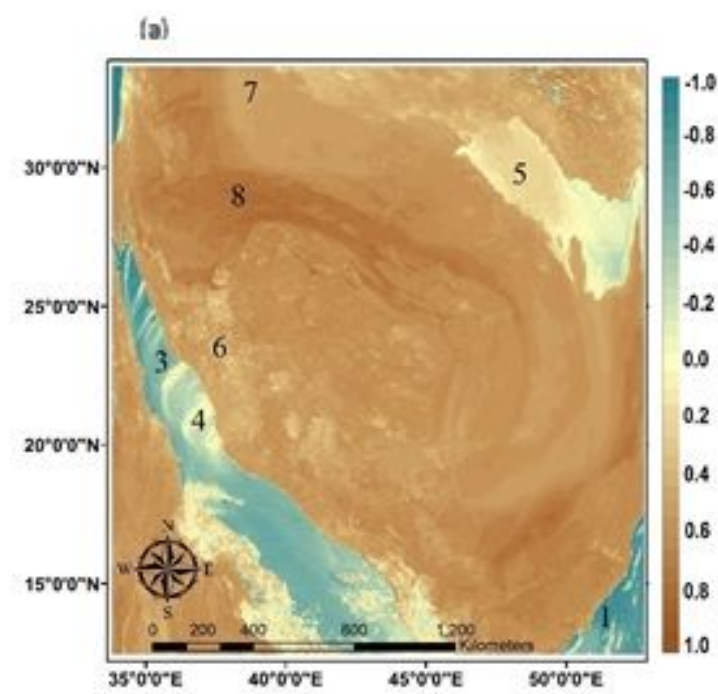

(c)

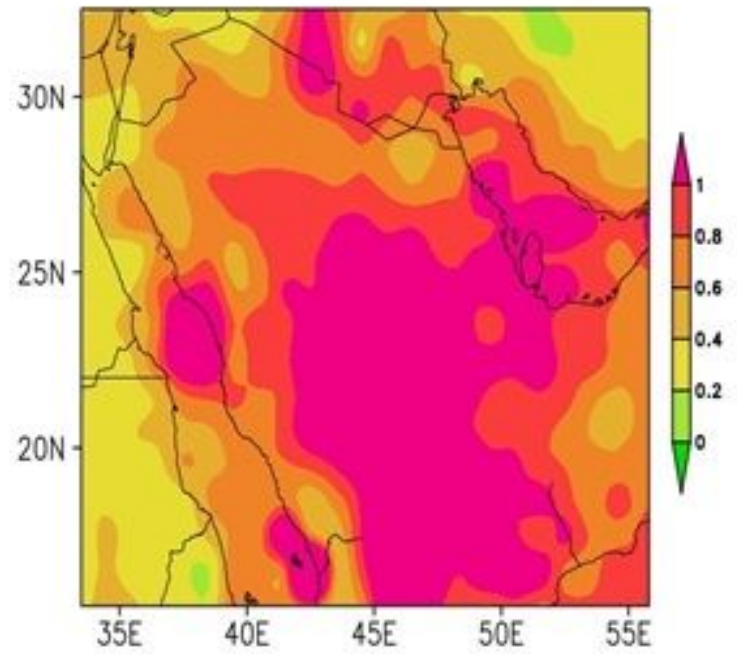

(b)

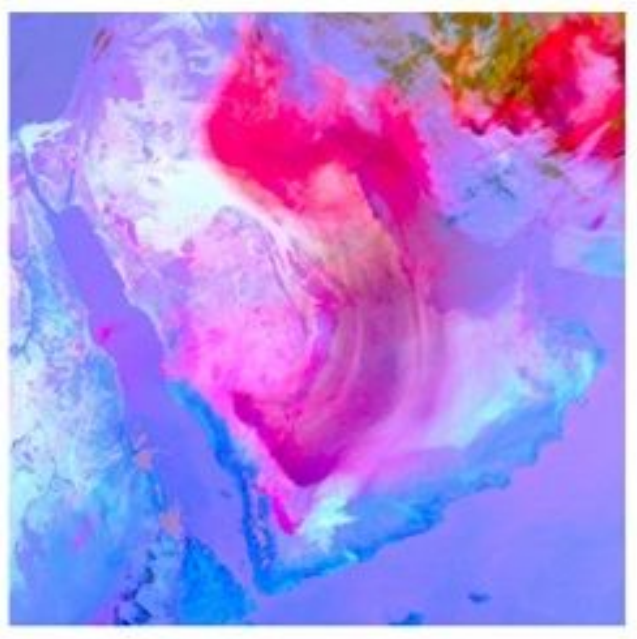

(d)

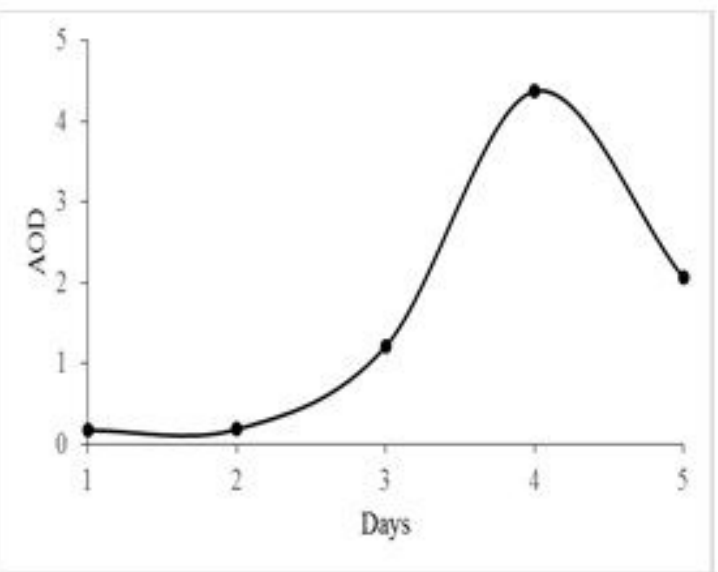

Figure 7

Sand and dust storm event of 18 March 2012 over the study area (a) MODIS GDDI image, (b) MSG image, (c) MODIS DT-DB AOD 5 day product, and (d) AERONET station data of AOD from KAUST for 5 days. 


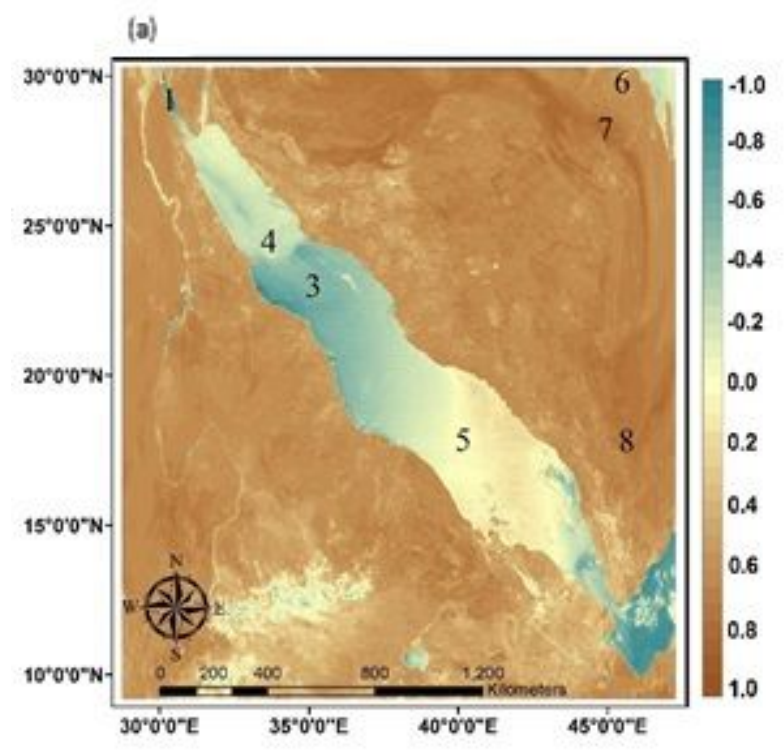

(c)

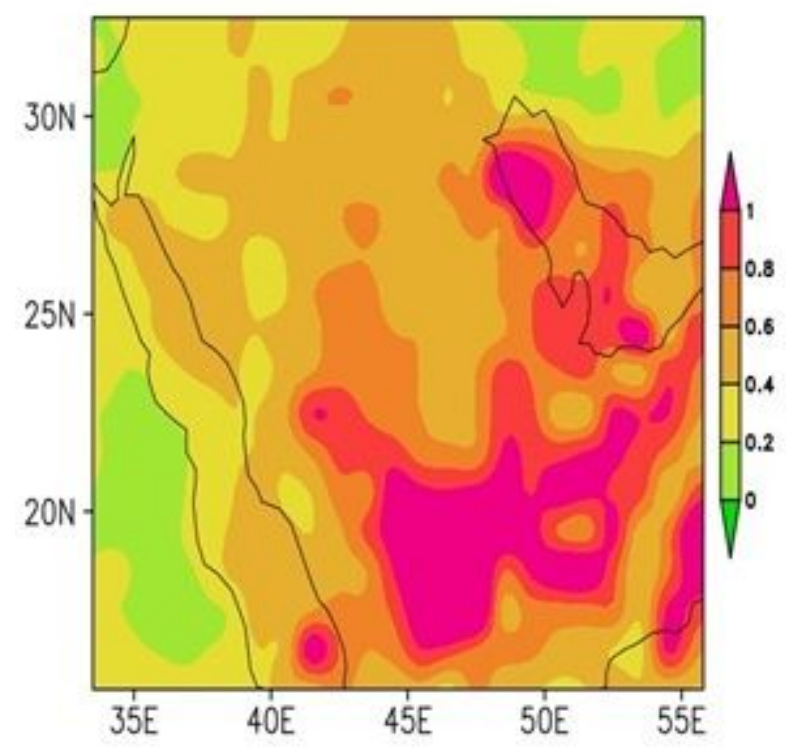

(b)

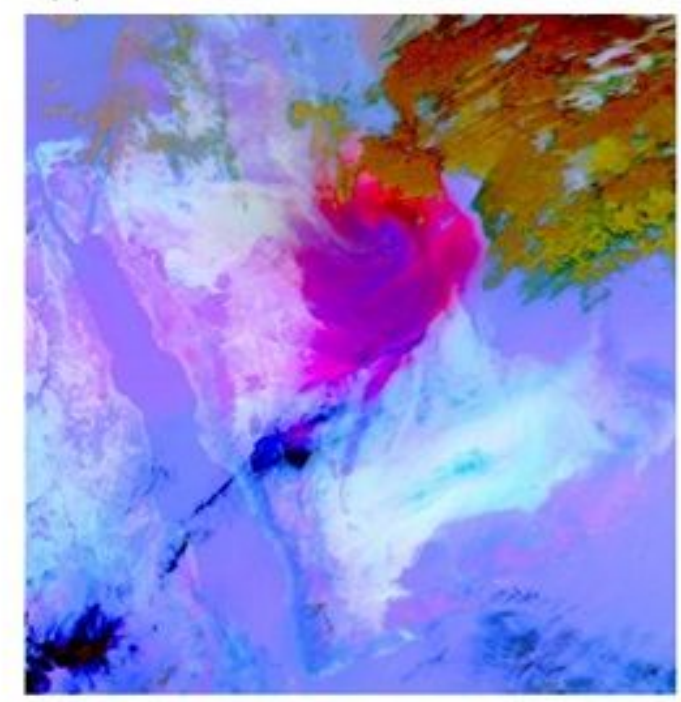

(d)

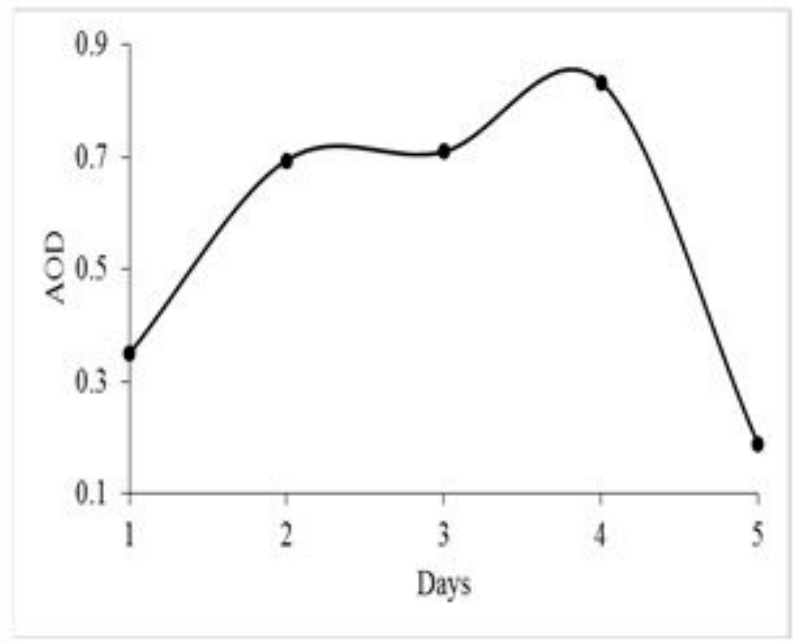

Figure 8

Sand and dust storm event of 1 April 2015 over the study area (a) MODIS GDDI image, (b) MSG image, (c) MODIS DT-DB AOD 5 day product, and (d) AERONET station data of AOD from Solar Village for 5 days. 